\title{
Characteristics of Buddhism in Australia
}

\section{MICHELLE SPULER}

ABSTRACT Research on Buddhism in Australia has tended to focus on demographics, ethnic identity and the migrant experience, and history. This paper uses the literature and material from Internet sites on Australian Buddhist groups to identify characteristics of Buddhism in Australia; it aims to both contribute to the understanding of the growth of Buddhism in Australia and to facilitate comparison with similar studies of American and European forms of Buddhism. New information is presented on the number of Buddhist groups in Australia, their geographical location, and the traditions and lineages represented. It is made apparent that more detailed information is needed, and suggestions are made for further research in a variety of areas.

\section{Introduction}

A number of recent studies have analysed common features of the diverse Buddhist traditions in America and Europe with the aim of defining uniquely American and European forms of Buddhism (Fields, 1987; Kornfield, 1988; Fields, 1992: 359-380; Schiller, 1994; Baumann, 1995a; Kantowsky, 1995; Prebish, 1995). Similar studies of other Western countries are needed to further the understanding of the expressions of Buddhism in individual countries and to provide information for international comparisons (Baumann, 1997b). Such research has not yet been undertaken on Buddhism in Australia. Existing literature focuses mainly on demographics, ethnic identity and the migrant experience, and history. ${ }^{1}$ As will be shown in this article, the analysis of this information provides a starting point for analysing the characteristics of Buddhism in Australia, allowing for comparison with international studies, but it also demonstrates the scarcity of the information available. ${ }^{2}$

\section{Demographics}

In order to understand the phenomenon of Buddhism in Australia it is useful to begin with some demographics; however, statistics are sparse. The major source of information is the Australian Bureau of Statistics census. In the 1996 Australian Bureau of Statistics census, 199,812 people or 1.1\% of the Australian population identified themselves as Buddhist. This represents an increase of $42.9 \%$ from the 1991 census. The real figure may be higher. The religion question on the census form provides no 'Buddhism' box to be ticked; Buddhists have to write their religion in by hand, a possible deterrent for non-English speaking respondents. In 1996, 1,604,749 people exercised their right not to answer the religion question (Hughes, 1997: 72). Naturally, the figure for Buddhists in Australia is well below those for the major Christian denominations: Catholics 
$(4,798,950)$, Anglicans $(3,909,324)$, Uniting Church $(1,334,917)$, Presbyterians and Reformed $(675,534)$, Orthodox $(474,921)$, Baptists $(295,178)$ and Lutherans $(249,989)$. However, Buddhists are now almost numerically equal with Muslims $(200,885)$; they outnumber Pentecostals $(174,720)$, Jehovah's Witnesses $(83,414)$, Jews $(79,805)$, Churches of Christ $(75,023)$, Salvation Army $(74,145)$, and Hindus $(67,279)$ (Hughes, 1997).

Other available census data on Buddhists in Australia includes gender, age, marital status, occupation, birthplace, education and income levels, and geographical spread. ${ }^{3}$ In 1996, nine people identified themselves on the census as both Buddhist and 'clergy', that is, as people whose primary occupation consisted in providing "motivation, guidance and training in religious life for the people of a congregation, parish or community" (Australian Bureau of Statistics, 1996). This statistic gives a grossly inaccurate picture; in 1994, there were at least twelve monks and two nuns from various Buddhist lineages resident in Brisbane alone (Spuler, 1994). In addition, the census classification does not allow for inclusion of Buddhist teachers for whom such work is not their primary occupation, as is the case with many lay teachers, and possibly some monastics.

The second major source of statistical information on Australian Buddhism are published studies of Buddhist organisations. In 1995, Humphreys and Ward identified 156 Australian Buddhist organisations and classified them by tradition/lineage and geographical location (Humphreys \& Ward, 1995). In 1996, Adam and Hughes published similar information; they identified 167 organisations (Adam \& Hughes, 1996). In January 1998, I sought to update this information by synthesising data from a number of sources. The two most useful listings of Australia Buddhist groups proved to be the Directory of the Buddhist Council of New South Wales and the Index of Buddhist Organisations in Australia of the BuddhaNet. These listed 260 and 233 groups, respectively.

I combined the information provided by these two databases with additional group listings obtained from Internet sites and publications focusing on specific Buddhist traditions and lineages or geographical areas, and from the Internet sites of Australian Buddhist groups (Spuler, 1994; Adam, 1995; Hasslacher, 1995; Mohr, 1997; BuddhaNet, 1998). This resulted in the identification of 308 Buddhist groups, almost double the figures of 1995 and 1996. However, it is difficult to determine the accuracy of this information. My database is a synthesis of numerous sources whose continuing accuracy is questionable-directories quickly become outdated. Consequently, it is difficult to know whether all the groups still exist or whether duplicate listings have occurred owing to organisational name or address changes. Furthermore, in some cases the 'organisation' listed may be an individual who provides a contact point for a particular lineage, rather than a practising group.

Table 1 classifies the 308 Australian Buddhist groups identified in my research by tradition/lineage and state or territory. ${ }^{4}$

The classifications used in this table reflect those employed by the various studies that were combined to yield this information. The classification of 'other non-sectarian' used in Table 1 includes ecumenical groups, communication networks, hospices, social action groups, libraries, bookstores, and journals. However, the classification of 'other' has been used in the remaining categories whenever a more detailed lineage classification was unavailable, and it does not necessarily indicate that those groups cannot be classified further. 
Table 1. Buddhist Organisations in Australia in January 1998

\begin{tabular}{|c|c|c|c|c|c|c|c|c|c|}
\hline Tradition/Lineage & $A C T$ & NSW & $N T$ & Qld & $S A$ & Tas & Vic & $W A$ & Total \\
\hline Theravada: & & & & & & & & & (86) \\
\hline Cambodian & 0 & 3 & 0 & 2 & 1 & 0 & 3 & 1 & 10 \\
\hline Lao & 1 & 5 & 0 & 1 & 0 & 0 & 2 & 0 & 9 \\
\hline Malaysian & 0 & 2 & 0 & 0 & 0 & 0 & 0 & 0 & 2 \\
\hline Myanmar & 0 & 2 & 0 & 0 & 0 & 0 & 0 & 2 & 4 \\
\hline Sri Lankan & 1 & 2 & 0 & 3 & 1 & 0 & 3 & 1 & 11 \\
\hline Thai & 1 & 6 & 0 & 1 & 1 & 0 & 4 & 2 & 15 \\
\hline Vipassana & 2 & 5 & 0 & 5 & 1 & 2 & 3 & 2 & 20 \\
\hline Other Theravada & 0 & 3 & 0 & 3 & 0 & 2 & 7 & 0 & 15 \\
\hline Mahayana: & & & & & & & & & (103) \\
\hline Chinese/Taiwanese: Fo Kuang Shan & 0 & 4 & 0 & 1 & 0 & 0 & 1 & 1 & 7 \\
\hline Other Chinese/Taiwanese & 0 & 12 & 0 & 3 & 2 & 0 & 3 & 0 & 20 \\
\hline Japanese: Jodo Shinshu & 0 & 1 & 0 & 1 & 1 & 0 & 0 & 0 & 3 \\
\hline Japanese: Soka Gakkai & 1 & 1 & 0 & 1 & 0 & 0 & 1 & 1 & 5 \\
\hline Japanese: Zen & 1 & 6 & 0 & 2 & 1 & 1 & 2 & 1 & 14 \\
\hline Other Japanese & 0 & 1 & 0 & 0 & 0 & 0 & 0 & 0 & 1 \\
\hline Korean: Zen & 0 & 0 & 0 & 1 & 0 & 0 & 0 & 0 & 1 \\
\hline Other Korean & 0 & 4 & 0 & 1 & 0 & 0 & 0 & 0 & 5 \\
\hline Vietnamese & 0 & 11 & 0 & 4 & 1 & 1 & 18 & 4 & 39 \\
\hline Other Mahayana & 0 & 1 & 0 & 0 & 0 & 1 & 5 & 1 & 8 \\
\hline Vajrayana (Tibetan): & & & & & & & & & (79) \\
\hline Gelug & 0 & 14 & 1 & 7 & 2 & 2 & 5 & 7 & 38 \\
\hline Karma Kagyu & 2 & 3 & 0 & 0 & 0 & 2 & 1 & 3 & 11 \\
\hline Nyingma (Dzogchen) & 2 & 7 & 0 & 1 & 0 & 0 & 2 & 1 & 13 \\
\hline Sakya & 1 & 1 & 0 & 1 & 0 & 0 & 0 & 0 & 3 \\
\hline Other Vajrayana & 1 & 7 & 1 & 0 & 4 & 0 & 1 & 0 & 14 \\
\hline Triyana (Western Buddhist): & & & & & & & & & (7) \\
\hline Friends of the Western Buddhist Order & 0 & 5 & 0 & 0 & 0 & 0 & 2 & 0 & 7 \\
\hline Non-sectarian: & & & & & & & & & (33) \\
\hline Student Societies & 1 & 6 & 0 & 0 & 0 & 0 & 3 & 0 & 10 \\
\hline Other Non-sectarian & 1 & 9 & 2 & 2 & 1 & 2 & 5 & 1 & 23 \\
\hline State Totals & 15 & 121 & 4 & 40 & 16 & 13 & 71 & 28 & 308 \\
\hline
\end{tabular}

The percentages of Buddhist groups represented by the main traditions and lineages are shown in Table 2.

Despite the large increase in the number of Australian Buddhist groups since the study by Adam and Hughes in 1996, there has been very little change in either the percentage of groups representing the major traditions and lineages or the geographical distribution of the groups, as indicated by Table 3.

Table 3 also demonstrates that there is a high correlation between the state distribution of Buddhist groups and the Buddhist population, as might be expected.

The census data and statistics on Buddhist organisations have been shown to provide some essential information on Buddhism in Australia. However, there are no available statistics to provide information, such as: breakdown of lay and monastic practitioners; number of teachers (and whether they are lay or mon- 
Table 2. Comparison of Traditions/Lineages Represented by Australian Buddhist Groups in 1996 and 1998

\begin{tabular}{|c|c|c|}
\hline Tradition/Lineage & Adam \& Hughes, 1996 & Spuler, 1998 \\
\hline Theravada & $29 \%$ & $28 \%$ \\
\hline Mahayana & $31 \%$ & $34 \%$ \\
\hline Vajrayana & $22 \%$ & $25 \%$ \\
\hline Triyana (Western Buddhist) & $2 \%$ & $2 \%$ \\
\hline Non-sectarian & $13 \%$ & $11 \%$ \\
\hline Other & $3 \%$ & - \\
\hline
\end{tabular}

astic); the extent of individuals' involvement in their Buddhist community; group demographics; organisational structures; group activities (such as meditation, rituals, social activities and community work); and facilities (such as monasteries and retreat centres).

Occasionally, some of this information can be gleaned from sociological studies. For example, Adam and Hughes note that of the Buddhist groups in Western Australia contacted for details of their activities, most offered Dharma talks, workshops or seminars, and meditation courses, and many had cultural festivals. Half of the groups had one or more ordained leaders in residence, usually monks, and most had lay leaders (Adam \& Hughes, 1996: 62-63). This information indicates the breadth of activities occurring in the Buddhist community and gives clues about the number of monastics resident in Western Australia; however, it is evident that more detailed research is required on these issues.

Despite the scarcity of available statistical information, it is possible to identify some key characteristics of Buddhism in Australia. Table 1 graphically demonstrates one characteristic that has already been noted by various scholars: diversity of traditions and lineages. ${ }^{5}$

Table 3. Geographical Distribution of Australian Buddhist Groups in 1996 and 1998, and of the Buddhist Population in 1996

\begin{tabular}{|c|c|c|c|}
\hline \multirow[b]{2}{*}{ State/Territory } & \multicolumn{2}{|c|}{ Buddhist Groups } & \multirow{2}{*}{$\begin{array}{c}\text { Buddhists } \\
1996 \text { Census }\end{array}$} \\
\hline & Adam \& Hughes, 1996 & Spuler, 1998 & \\
\hline Australian Capital Territory & - & $5 \%$ & $2 \%$ \\
\hline New South Wales & $41 \%$ & $40 \%$ & $41 \%$ \\
\hline Northern Territory & $2 \%$ & $1 \%$ & $1 \%$ \\
\hline Queensland & $17 \%$ & $13 \%$ & $9 \%$ \\
\hline South Australia & $5 \%$ & $5 \%$ & $6 \%$ \\
\hline Tasmania & $4 \%$ & $4 \%$ & $1 \%$ \\
\hline Victoria & $20 \%$ & $23 \%$ & $31 \%$ \\
\hline Western Australia & $11 \%$ & $9 \%$ & $9 \%$ \\
\hline
\end{tabular}

\section{Ethnic Identity and the Migrant Experience}

Given the large numbers of immigrant Buddhists, many studies on Buddhism in Australia focus on the effects of religion on ethnic identity and the migrant 
experience. Like many of their international counterparts, studies on Buddhism in Australia commonly distinguish two main types: convert (also called 'nonethnic', 'white', 'non-Asian' or 'Anglo-Saxon') Buddhism and ethnic (or 'Asian' or 'immigrant') Buddhism. For example, Prebish discusses the use of this terminology in American Buddhism (Prebish, 1996). Examples of its application to European Buddhism can be seen in Baumann's differentiation between Asian and European Buddhists (Baumann, 1995a: 64). Bucknell discusses ethnic Buddhists and Australian Buddhists of non-Asian origin (Bucknell, 1992: 213); and Adam and Hughes's discussion on Australian Buddhism distinguishes two categories: Western Buddhist and ethnic Buddhist Groups (Adam \& Hughes, 1996: 7-11). Convert Buddhists are usually mainly interested in meditation practice or the study of Buddhist philosophy and often do not classify themselves as Buddhists. In contrast, ethnic Buddhists are usually born Buddhists and practise Buddhism within a specific cultural context. Ethnic Buddhist groups often combine Buddhist practice with a wide variety of social and cultural activities that assist in the maintenance of their cultural identity.

The majority of Australian Buddhists comprises ethnic Buddhists; the 1996 census showed that the largest percentages of Australian Buddhists by birthplace were: Vietnam 31\%, Australia 19.7\%, Malaysia 7.5\%, Cambodia 6.8\%, Thailand 6.2\%, Sri Lanka 5.2\%, China 4.6\%, Laos 3.4\%, Taiwan $2.5 \%$, and Indonesia 2.2\% (Hughes, 1997: 17). In 1991, only 14\% of Australian Buddhists had been born in Australia (Adam \& Hughes, 1996: 43), the increase to 19.7\% by 1996 is probably more due to the birth of second-generation ethnic Buddhists than to an increase in converts.

Although Malaysian-born Buddhists are the second largest ethnic group by birth, there are no Malaysian groups listed in Table 1. Malaysians seem to be attending other groups instead of forming their own; for example, the Buddhist Society of Western Australia is multi-cultural in composition, with members from Thailand, Burma, Sri Lanka, India, Malaysia, China, Laos, Cambodia, and Indonesia (Adam, 1995: 29). Similarly, the Australian Mahayana Buddhist Society has members from Indonesia, Malaysia, Hong Kong, and Vietnam (Adam, 1995: 48).

This identification of two main strands is relevant to the identification of characteristics of Australian Buddhism, because the literature reveals that ethnic Buddhists face prejudices that convert Buddhists do not. Existing analysis is again limited; however, various studies document difficulties encountered by ethnic Buddhists, particularly at local government level (Croucher, 1989: 104105; Lyall, 1989: 12-16; Lyall, 1994: 30-35; Adam \& Hughes, 1996: 55). A number of studies have examined ethnic Buddhists in Australia in the context of the relationship between religion and ethnic identity or the migrant experience, examining in particular the effects of ethnic religious activity on cultural adjustment. Cox (1982) examines the role of religion in migrant welfare, comparing Buddhist and Muslim families from eight different ethnic backgrounds; Adam (1995) investigates whether religion provides a source of alienation or a means to integration for Vietnamese Buddhist and Catholic migrants in Western Australia; and Bouma's (1996) work on religious settlement, identity, and cultural diversity in Australia includes case studies of Vietnamese Buddhist migrants. These studies could be analysed to identify further characteristics of ethnic Buddhism in Australia. 
The recognition of the existence of two strands of Buddhism in Australia is not generally viewed as problematic by scholars, the vast majority of studies on Buddhism in Australia have given the different strands of Australian Buddhism equal attention, avoiding the preferential treatment sometimes given to convert Buddhism in America. Numrich notes that most surveys of Buddhism in America concentrate on the American-convert experience, examining how primarily non-Asian Buddhist practitioners will forge a new "American Buddhism" (Numrich, 1996: xxii). Similarly, Fields presents evidence that it is mainly 'white' Buddhists who are doing the defining in discussions on emergent American Buddhism (Fields, 1994: 55).

\section{Historical Periodisation}

In order to determine key characteristics of contemporary Buddhism in Australia it would be useful to identify the significant periods in the development of Buddhism in this country and to compare the current situation with the characteristics of earlier periods. Baumann has used this approach to identify the processes and strategies involved in the transplantation of Buddhism to Germany, using historical data to provide information on religious adaptation (Baumann, 1994; Baumann, 1995a; Baumann, 1996). A number of historical accounts of Buddhism in Australia are available, most notably that by Croucher (Croucher, 1989; McDonnell \& Bucknell, 1988; Bucknell, 1992; Adam, 1995; Humphreys \& Ward, 1995; Adam \& Hughes, 1996). Although these chronicles generally discuss the same key events, there has been no attempt at periodisation or analysis comparable to that undertaken by Baumann.

In order to test the usefulness of an analysis based on historical periodisation of Australian Buddhism, I have undertaken a brief survey of these historical publications and identified six key periods: 1) immigrant origins, 2) the first organisations, 3) the first visits by teachers, 4) the first residential teachers and establishment of monasteries, 5) rapid Asian immigration and increasing diversification of traditions present in Australia, and 6) the emergence of ecumenical Buddhist societies. Despite the cursory nature of my examination of the historical data, characteristics of these different periods are beginning to emerge, confirming the need for a more detailed study. Croucher's in-depth historical study of Buddhism in Australia from 1848 to 1988 provides many excellent examples that reveal such characteristics; however, it does not draw attention to commonalties or identify trends.

1) Immigrant origins: Buddhism probably first reached Australia in 1848 , with the arrival of Chinese immigrants to work in the gold fields. However, Chinese religion is highly syncretic and the initial Buddhist influence was only slight. In approximately 1870, a number of Sri Lankan immigrants, most of whom were Buddhist, settled in the Mackay area of Queensland. As early as 1876, a large group of Sri Lankans also settled on Thursday Island; by the 1890s, the community totalled about 500 people.

2) First organisations: The first documented Buddhist organisation in Australia was the Little Circle of Dharma, founded in Melbourne in 1925 by convert Buddhists who had gained experience of Buddhism in Burma. In 1938, a second 
group, the Buddhist Study Group, formed in Melbourne, aiming "to promote interest in Buddhism as a workable psychology adaptable for modern problems" (quoted from a pamphlet distributed by the group; Croucher, 1989: 28). This is the first evidence of secularisation of Buddhism in Australia, a characteristic shared with contemporary American and European Buddhism. Khantipalo Thera notes in his Foreword to Croucher's book that "Early Australian Buddhists, and sympathisers of Buddhism, were mostly attracted to the rationalhumanistic side of the teachings or to their artistic manifestations" (Khantipalo, 1989).

3) First visits by teachers: In 1952, an American-born Buddhist nun, Sister Dhammadinna, was funded by the World Fellowship of Buddhists to visit Australia. Her visit caused the first enduring Buddhist society to form, the Buddhist Society of New South Wales, which was established in 1952. The first fully ordained Buddhist monk, U Thittila, a Burmese Theravada monk, visited in 1954. In 1958, the Buddhist Federation of Australia formed as the first ecumenical group and became a regional member of the World Federation of Buddhists. While early Australian interest in Buddhism had focused mainly on Theravada, interest in other traditions and lineages was beginning to develop, with teachers visiting from a variety of traditions. For example, the first Soka Gakkai group formed in 1964 after a visit from the international president, Daisaku Ikeda.

Women played a key role in Australian Buddhism during this time-another characteristic shared with Buddhism in America and Europe. One prominent woman Buddhist was Marie Byles who had begun disseminating her Buddhist beliefs through articles and books after World War II. Another was Natasha Jackson of whom Croucher writes: "As the editor of the bimonthly journal, Metta: The Journal of the Buddhist Federation of Australia, Natasha Jackson was the dominant voice in Australian Buddhism from 1955 to 1971." (Croucher, 1989: 37)

During this period, Buddhism was still very secular in orientation. According to Croucher, Natasha Jackson and Charles F. Knight (the first chairman of the Buddhist Federation of Australia) "saw Buddhism as a triumph of rationalism and used it as a foil in their attacks on Christianity. It was a strongly intellectualised approach, going to great lengths to prove that Buddhism was fully consonant with scientific thinking." (Croucher, 1989: 54-55) Jackson and Knight were also concerned with the relationship between Buddhism and social ethics. Both supported Aboriginal land rights and protests against the Vietnam War; Jackson is quoted as saying: "of what use is the empty chanting of the Metta Sutta while nothing is done to banish poverty, illiteracy, lack of hygiene and sanitation?" (Croucher, 1989: 76).

4) First residential teachers and establishment of monasteries: In 1971, the Buddhist Society of New South Wales arranged for a Sri Lankan monk, Somaloka, to take up residence. He established the first Buddhist monastery in Australia in Katoomba, New South Wales. In 1974, an English-born, Thai-trained monk, Khantipalo Thera, established a second Theravada monastery, Wat Buddharangsee in Stanmore, New South Wales. 
Table 4. Vajrayana Gelug Organisations in Australia in January 1998

\begin{tabular}{lccccccccc}
\hline Lineage: Gelug & ACT & NSW & NT & Qld & SA & Tas & Vic & WA & Total \\
\hline FPMT & 0 & 3 & 0 & 3 & 2 & 0 & 4 & 3 & $\mathbf{1 5}$ \\
IBLP and AITMP $^{6}$ & 0 & 7 & 1 & 2 & 0 & 0 & 0 & 1 & $\mathbf{1 1}$ \\
New Kadampa Tradition & 0 & 0 & 0 & 0 & 0 & 0 & 0 & 1 & $\mathbf{1}$ \\
Tibetan Buddhist Society & 0 & 3 & 0 & 1 & 0 & 0 & 1 & 2 & $\mathbf{7}$ \\
Other Gelug & 0 & 1 & 0 & 1 & 0 & 2 & 0 & 0 & $\mathbf{4}$ \\
State Totals & $\mathbf{0}$ & $\mathbf{1 3}$ & $\mathbf{1}$ & $\mathbf{7}$ & $\mathbf{2}$ & $\mathbf{2}$ & $\mathbf{5}$ & $\mathbf{7}$ & $\mathbf{3 8}$ \\
\hline
\end{tabular}

5) Rapid Asian immigration and increasing diversification of traditions present in Australia: With the ending of the Vietnam War in 1974-75, refugees from Laos, Cambodia and Vietnam arrived in Australia in large numbers. Laotian and Cambodian Buddhists tended to form Buddhist organisations together because of shared Theravadan heritage, while the Mahayana Vietnamese Buddhists established separate groups. The Vietnamese groups were further strengthened by the arrival of resident Vietnamese monks in the early 1980s.

A small number of Tibetan refugees also arrived about this time. 1974 saw the first visit by Tibetan lamas, Lama Thubten Yeshe and Lama Thubten Zopa, the founders of the Foundation for the Preservation of the Mahayana Tradition (FPMT), which is part of the Vajrayana Gelug tradition. During their visit the two lamas held the first Tibetan Buddhist retreat in Mooloolabi, Diamond Valley, Queensland, a one-month meditation course attended by around two hundred people (McKimm, 1975). The Chenrezig Institute for Wisdom Culture was established soon after in Eudlo, Queensland, as the first FPMT centre in Australia. The FPMT is the largest of the Tibetan Gelug groups represented in Australia, as shown in Table 4.

McDonnell and Bucknell note that while the Tibetan influx has been small, it has had a disproportionately strong influence on Buddhism in Australia (McDonnell \& Bucknell, 1988: 324). As Table 2 demonstrates, despite its relatively recent establishment in Australia, Tibetan Buddhism currently accounts for $25 \%$ of Australian Buddhist groups.

The variety of Buddhist traditions present in Australia continued to diversify with the establishment of the first Zen centre, the Sydney Zen Centre, in 1976. The Sydney Zen Centre established close associations with the Diamond Sangha when the head of the Diamond Sangha, Robert Aitken Roshi, arrived in 1979 to lead the first Australian Zen retreat. Since then a number of different Zen Buddhist groups with Japanese origins have developed in Australia; however, Table 5 demonstrates that the Diamond Sangha affiliates are the largest group.

6) Emergence of ecumenical Buddhist societies: The literature indicates that ecumenical efforts between Australian Buddhist organisations are more common than rivalry. To add to the already existing ecumenical body, the Buddhist Federation of Australia, a number of other ecumenical bodies formed following the diversification of lineages present in Australia. These included the Buddhist Council of Brisbane in 1982, which combined ten groups from different traditions and lineages (McDonnell, 1986), and the Buddhist Council of New South Wales in 1985. Ecumenical groups promote themselves as useful in assisting 
Table 5. Japanese Zen Buddhist Organisations in Australia in January 1998

\begin{tabular}{lccccccccc}
\hline Lineage: Japanese Zen & $A C T$ & NSW & NT & Qld & SA & Tas & Vic & WA & Total \\
\hline Zen Lineage of Master Deshimaru & 0 & 1 & 0 & 0 & 0 & 0 & 0 & 0 & $\mathbf{1}$ \\
Diamond Sangha & 1 & 2 & 0 & 0 & 1 & 0 & 1 & 1 & $\mathbf{6}$ \\
Ordinary Mind Zen School & 0 & 0 & 0 & 1 & 0 & 1 & 0 & 0 & $\mathbf{2}$ \\
Open Way & 0 & 2 & 0 & 0 & 0 & 0 & 0 & 0 & $\mathbf{2}$ \\
Sanbo Kyodan & 0 & 1 & 0 & 1 & 0 & 0 & 0 & 0 & $\mathbf{2}$ \\
Other Japanese Zen & 0 & 0 & 0 & 0 & 0 & 0 & 1 & 0 & $\mathbf{1}$ \\
State Totals & $\mathbf{1}$ & $\mathbf{6}$ & $\mathbf{0}$ & $\mathbf{2}$ & $\mathbf{1}$ & $\mathbf{1}$ & $\mathbf{2}$ & $\mathbf{1}$ & $\mathbf{1 4}$ \\
\hline
\end{tabular}

Australian Buddhists from different traditions to achieve common goals and to have a visible and active presence in the community, particularly with regard to representation to the various levels of government (Gamble, 1986; McDonnell, 1986; Buddhist Federation of Australia, 1988; Croucher, 1989; Lyall, 1989: 25-26; Humphreys \& Ward, 1995: 410). Isolated examples of prejudice between Buddhist groups can be found: Croucher noted in 1988 that many convert Buddhists "look down their noses at the non-meditative aspects of ethnic temple religion" (Croucher, 1989: 105).

However, some scholars have suggested that the achievements of such ecumenical groups are limited. Bucknell maintains that the bonds forged by inter-traditional ecumenical bodies are weak in comparison with those that exist within federations of groups from the same tradition or lineage. Examples of the latter are the United Vietnamese Buddhist Congregation of Australia and New Zealand (formerly the Vietnamese Buddhist Federation of Australia, established in 1979), to which many Vietnamese groups belong; and the FPMT, a Paris-based international body, which has currently 15 Australian member groups. Bucknell concludes that "There seems ... little likelihood of any strong move toward genuine unity among the various types of Buddhist groups in Australia" (Bucknell, 1992: 222). Similarly, Humphreys and Ward note of the Australian situation that "Because of their faith's stress on individual spiritual development and their varied cultural background in Australia, local Buddhists have shown little support for organisational unity" (Humphreys \& Ward, 1995: 410). Bucknell also cites the individual and private nature of Buddhist practice as a reason (Bucknell, 1992: 222-223).

It is apparent that the ecumenical bodies of Australian Buddhism have not achieved the same successes as some of their overseas counterparts. In 1991, the European Buddhist Union consisted of 30 members (themselves national ecumenical organisations) from 11 countries (Baumann, 1995a: 65). There is scarce mention of cross-lineage and cross-religion borrowing in studies on Buddhism in Australia; for example, Croucher discusses a possible synthesis between Theravada and Zen Buddhism (Croucher, 1989: 117). In contrast, such borrowing is often mentioned as characteristic of American Buddhism. ${ }^{7}$ Croucher provides some examples of inter-religious dialogue, such as a colloquium held on Zen by the Melbourne Quakers in 1973 (Croucher, 1989: 110-112), and both Croucher and Bucknell note increasing interest in Buddhist meditation by Christian clergy, particularly Catholics (Croucher, 1989: 110-112; Bucknell, 1992: 221).

On the subject of ecumenism, Croucher wrote in 1989: 
The history of Buddhism in Australia has in many respects been bifurcated and oppositional, with Theravadins pitted against Mahayanists, the vehemently anti-Christian against eclectics, traditionalists against iconoclasts and, most recently, the 12,000 or so Anglo-Australian Buddhists against their 70,000 Asian-Australian counterparts. In the late 1980s sectarian rivalries have probably become less pronounced; but while some kind of Theravada-Zen synthesis may be envisaged, for the most part different groups will probably do their best to maintain separate identities in an atmosphere of respect and interactive pluralism. (Croucher, 1989: 123)

The continuing increase in the number of groups and lineages represented indicates that Buddhism in Australia will remain pluralistic. Diversity of lineage is also characteristic of American and European Buddhism (Schiller, 1994: 74). In his narrative history of Buddhism in America Fields writes:

Perhaps we cannot yet talk of an American Buddhism in the same way we might talk about, say, Chinese or Tibetan Buddhism, and yet we can certainly talk about an American Buddhist lineage-one that is woven of lineages from all over the Buddhist world, as well as from certain strands that are characteristically American. (Fields, 1992: xiv)

Similarly, Baumann, in his analysis of historical and contemporary developments of Buddhism in Europe, observes that

Buddhism in Europe is deeply marked by its heterogeneous and diverse appearance. A multitude of sub-schools, sub-branches and independent centres, each focusing more or less entirely on the particular interpretation of the respective teacher, has evolved. It is difficult to imagine that a unified, jointly practised 'European Buddhism' will emerge in the next century. (Baumann, 1995a: 65)

\section{Comparisons with American and European Buddhism}

Studies of American and European Buddhism have identified a number of characteristics that have not previously been reported in analyses of Australian Buddhism: emphasis on lay practice, equality for women, application of democratic principles, emphasis on ethics, secularisation (this includes emphasis on the rational nature of Buddhism and its congruence with Western science), and linkage to psychological concepts.

If differences between Australian, American and European forms of Buddhism can be identified, this may provide information about the different cultural factors affecting the development of Buddhism in these countries. In his review of Tweed's research on the early adoption of Buddhist ideas in America, Baumann notes that "While examining public and personal attitudes to a transplanted, 'exotic' religion, Tweed succeeds in elucidating the prevalent beliefs and values of the dominant culture" (Baumann, 1995b). In his own research Baumann examines rationalist conceptions of Buddhism in Germany and argues that Germany has interpreted and presented Buddhism in a way that conforms with German values; he concludes that the Buddhism that has developed in Germany says more about German cultural values and attitudes than about Buddhism itself (Baumann, 1997a: 287). 
However, most of the Buddhist lineages found in Australia are also represented in America and Europe; indeed many Australian lineages have their origins or current headquarters in other Western countries. It therefore seems likely that the majority of the characteristics of American and European Buddhism would be shared by Australian Buddhism. While these characteristics have not been documented in studies of Australian Buddhism, some Australian examples can be found.

Evidence that Australian Buddhism is following the Western trend of emphasising lay practice includes the growth of groups affiliated with lineages that are no longer monastic, such as the Sanbo Kyodan and the Diamond Sangha. However, there are also many organisations that support large monastic communities. Examples include the Bodhinyana Monastery, which includes a training centre for Theravada monastics in the Thai Forest tradition (Adam, 1995: 105); the Chenrezig Institute for Wisdom Culture, a residential centre of the FPMT; and the Linh Son Temple, a nunnery that is a branch of the Linh Son World Buddhist Association. In order to determine whether the emphasis in Australian Buddhism is on lay or monastic practice it would be necessary to have statistics which provide details about the number of lay and monastic practitioners as well as information on the activities of the monastic groups, to examine whether lay practice is also promoted. Until such information is available, it cannot be determined whether emphasis on lay practice is a characteristic of Buddhism in Australia.

Similarly, an emphasis on equality for women is not yet apparent in Australian Buddhist groups, despite some historical and contemporary examples. As Adam and Hughes observe, the role of women varies in Buddhist traditions and countries, and this is reflected in the role of women in Australian Buddhist groups (Adam \& Hughes, 1996: 35). A cursory glance through the Internet sites of Australian groups reveals that many teachers, particularly monastics, are male, yet some groups do have female teachers (either lay or monastic)-for example, Ms Subhana Barzaghi Roshi is the main teacher of both the Sydney Zen Centre and the Kuan Yin Zen Centre (both affiliates of the Diamond Sangha) and an American nun, Kwang Myong Sunim, leads the Dae Kwang Sa Zen Society (part of the Kwan Um school of Korean Chogye Buddhism). Other examples of increasing equality for women include the Buddhist Society of Western Australia's recent acquisition of land for a monastery for nuns, which is to complement the existing monastery for monks, Bodhinyana (Buddhist Society of Western Australia, 1998).

The application of democratic principles within Australian Buddhism is demonstrated by the existence of elected councils. However, in most organisations, these bodies usually concentrate on the administration of the organisation, leaving the spiritual side (admittedly a difficult distinction) in the hands of teachers who may or may not have been chosen by the congregation. My research on Diamond Sangha Zen Buddhist groups in Australia has revealed that although there are some community decision-making processes on spiritual matters, most decisions are still made by teachers and/or senior students.

Some emphasis on social engagement is evident in Australian Buddhist groups, as a number of organisations focus on provision of community services. Bucknell notes that there are two main types of services provided by these organisations: provision of hospice care services and promotion of development 
projects in overseas countries (Bucknell, forthcoming). Examples include the Karuna Hospice Service, a Buddhist-based, home-care nursing service for individuals who have a diagnosed life-threatening illness, the Amitayus Hospice Service, a similar home-based palliative care and support service which operates "with the values and principles of Buddhist teachings as our guiding light" (Amitayus Hospice Service, n.d.), and an Australian branch of the Buddhist Peace Fellowship, an international organisation that encourages Buddhists "to explore personal and group responses to political, social, and ecological suffering in the world" (Buddhist Peace Fellowship, 1998).

The evidence of secularisation in early Australian Buddhism has already been cited. Yeshe Khadro, former director of the Chenrezig Institute for Wisdom Culture, indicates that secularisation of Buddhist groups and links to psychological practice also exist in contemporary Buddhism:

Visitors coming to Chenrezig often want to learn Buddhist techniques that will help them overcome problems in their life. Not so many visitors want, or have the time, to undertake an extensive study of Buddhist philosophy. To try to meet this need, we have added the study of various types of Western psychology, science, teaching and counselling techniques to our traditional Buddhist studies education program. (Khadro, 1995: 124)

Similarly, Bucknell writes:

Interest in Buddhist techniques of meditation is growing steadily. Meditation centres scattered around the country attract not only people who would call themselves Buddhists, but also psychologists, therapists and ordinary people seeking such tangible benefits as relief from stress. These experimenting meditators, exploring the ancient practices for developing concentration and insight, are finding them to have a range of valuable applications in the modern western context. (Bucknell, 1992: 223)

However, there are also those who object to merging Buddhist practice with psychology and psychotherapy. Patrick Kearney, a Vipassana teacher at the Blue Mountains Insight Meditation Centre, spoke on this issue at the Buddhist Library and Meditation Centre in Sydney in April 1998, concluding that

Buddhism is not a collection of spiritual or therapeutic techniques. Buddhism is an ocean. If we want we are free to paddle on the edge of the shore, trying a technique here or a therapy there, occasionally getting our feet wet, but staying safely within our limitations. Or we can take the advice of Dogen Zenji, who said: "Arouse the mind that seeks the way, and plunge into the ocean of Buddhism." Ultimately the future of Buddhism in the West will be decided by those who take the plunge, because the paddlers will always draw back and, rather than adapt Buddhism to its new home, will develop new forms of Buddhised psychotherapy. For ultimately we must choose whom we will follow. We can follow Buddha or we can follow Freud; we cannot do both, because they are just not travelling in the same direction. (Kearney, n.d.) 


\section{Conclusion}

In summary, the characteristics of contemporary Buddhism in Australia that are identifiable from the existing literature are: differentiation between ethnic and convert Buddhism, diversity of lineages, varied ethnic composition, and to some extent, ecumenism. These are also the features of American and European Buddhism. It is possible that Australian Buddhism also shares other characteristics with American and European Buddhism. Examples of such characteristics can certainly be found in Australian Buddhism; however, further research must be undertaken before it can be concluded that these are more than isolated cases.

In order to increase understanding of Australian Buddhism at individual, organisational, and societal levels, at least three types of study will be useful. Firstly, studies that involve interviewing Buddhist practitioners regarding issues such as religiosity and conversion, and thus go beyond existing knowledge with its focus on the Buddhist migrant experience. Secondly, studies that contact Australian Buddhist groups directly to gather information regarding group history, lineage, teacher and student demographics, activities, and facilities. Thirdly, studies that examine the relationship between Buddhism and the wider Australian society and culture both now and in the past. Individual conversion accounts could be combined with research in public attitudes towards Buddhism and the integration of Buddhist ideas and practices into mainstream culture; this would provide insights into the motivations behind the development of certain characteristics in Australian Buddhism. All of this research will ideally be based on fieldwork; however, useful information can be gleaned from publications such as group newsletters and Internet sites, as was done in the research for this paper.

Michelle Spuler has completed her Ph.D. thesis in the Department of Studies in Religion, University of Queensland, under the supervision of Dr Rod Bucknell and Dr Lynne Hume. Her research focused on the acculturation process in Diamond Sangha Zen Buddhist groups in Australia. Correspondence: Department of Studies in Religion, University of Queensland, 4072, Australia. E-mail: MSpuler@hotmail.com

\section{NOTES}

1. A comprehensive bibliography of sources on Buddhism in Australia is provided by Spuler, 1998 .

2. This article is based on a paper which I presented to the Australian Association for the Study of Religions conference in Melbourne, Australia, 4 July, 1998. I would like to thank the following people for their assistance with this research: Enid Adam, Dr Martin Baumann, Dr Rod Bucknell, Dr Philip Hughes, Dr Lynne Hume, and Patrick Kearney.

3. Excellent statistical information based on the 1996 census is available in Hughes, 1997: 14-17; more detailed analysis of the 1991 census data is provided by Adam \& Hughes, 1996.

4. The abbreviations used are: Australian Capital Territory (ACT), New South Wales (NSW), Northern Territory (NT), Queensland (Qld), South Australia (SA), Tasmania (Tas), Victoria (Vic), and Western Australia (WA).

5. For example, see McDonnell \& Bucknell, 1988: 25.

6. The Institute of Buddhist Learning and Practice (IBLP) and the Australian Institute of Tibetan Medical Practices (AITMP) are separate organisations; however, as both are directed by Khejok Rinpoche, they are closely related.

7. One example is provided by Fields, 1987: 24. 


\section{REFERENCES}

Adam, Enid. Buddhism in Western Australia. Perth: The Author, 1995.

Adam, Enid \& Hughes, Philip J. The Buddhists in Australia. Religious Community Profiles series. Canberra: Australian Government Publishing Service, 1996.

Amitayus Hospice Service. http://amitayus.24.com.au/WhatWeDo.html. n.d. Information obtained on 20th May, 1998.

Australian Bureau of Statistics. 1996 National Population and Housing Census. cmatrix file "cra2tab2.dat".

Australian Institute of Buddhist Learning and Practice Centres. http://www.buddhanet.net/ba25.htm. n.d. Information obtained on 26th November, 1998.

Baumann, Martin. "Culture Contact and Valuation: Early German Buddhists and the Creation of a 'Buddhism in Protestant Shape'." Numen 44 (September), 1997a: 270-295.

Baumann, Martin. "The Dharma Has Come West: A Survey of Recent Studies and Sources." Journal of Buddhist Ethics 4, 1997b: 194-211. http://jbe.la.psu.edu/4/baum2.html. Information obtained on 26th November, 1998.

Baumann, Martin. "Buddhism in the West: Phases, Orders and the Creation of an Integrative Buddhism." Internationales Asienforum (International Quarterly for Asian Studies) 27 (3-4), 1996: 345-362.

Baumann, Martin. "Creating a European Path to Nirvana: Historical and Contemporary Developments of Buddhism in Europe." Journal of Contemporary Religion 10 (1), 1995a: 55-70.

Baumann, Martin. "Review of The American Encounter with Buddhism 1844-1912 by Thomas A. Tweed." Journal of Contemporary Religion 10 (2), 1995b: 217-219.

Baumann, Martin. "The Transplantation of Buddhism to Germany: Processive Modes and Strategies of Adaptation." Method and Theory in the Study of Religion 6 (1), 1994: 35-61.

Bentley, Peter. "Religious Community Profiles." Australian Religious Studies Review 10(1), 1997: 47-65.

Bouma, Gary D., ed. Many Religions, All Australian. Melbourne: Christian Research Association, 1996.

Bouma, Gary D. "The Emergence of Religious Plurality in Australia: A Multicultural Society." Sociology of Religion 56 (3), 1995: 285-303.

Bouma, Gary D. "Engaged Buddhism in Australia." In Queen, C., ed. Engaged Buddhism in the West. Forthcoming. Boulder, CO: Wisdom.

Bucknell, Roderick S. "The Buddhist Experience in Australia." In Habel, N., ed. Religion and Multiculturalism in Australia: Essays in Honour of Victor Hayes. Special Studies in Religion Series, No. 7. Adelaide: Australian Association for the Study of Religions, 1992: 214-224.

Buddhist Centres of the Karma Kagyu Lineage in Australia. http://www.diamondway-buddhism.org/ centers/z-au.htm. 24th January 1998. Information obtained on 26th November, 1998.

BuddhaNet. Australian Web Sites \& Profiles of Centres. http://www.buddhanet.net/ba_index.htm. 1998. Information obtained on 26th June, 1998.

BuddhaNet. Index of Buddhist Organisations in Australia. http://www.buddhanet.net/baorgs.htm. n.d. Information obtained on 26th June, 1998.

BuddhaNet. National Index of Australian Meditation Groups. http://www.buddhanet.net/ whats_m.htm. n.d. Information obtained on 15th June, 1998.

Buddhist Centres of the Karma Kagyu Lineage in Australia. http://www.diamondway-buddhism.org/ centers/z-au.htm. 24th January, 1998. Information obtained on 26th November, 1998.

Buddhist Council of New South Wales. 1996 Census Shows that Buddhism is Still Australia's Fastest Growing Religion. http://www.zip.com.au / lyallg/cencom.htm. n.d. Information obtained on 14th January, 1999.

Buddhist Council of New South Wales. Analysis of Religious Growth in Australia and New South Wales 1986-1996. http://www.zip.com.au / lyallg/census1.htm. n.d. Information obtained on 14th January, 1999.

Buddhist Council of New South Wales. Buddhist Council of New South Wales: Its Past, Present and Future. http://www.zip.com.au/ lyallg/bcgrnd.htm. n.d. Information obtained on 26th November, 1998.

Buddhist Council of New South Wales. Buddhist Organisations in Australia. http:/ /www.zip.com.au / $\sim$ lyallg/index.htm. n.d. Information obtained on 15th January, 1999.

Buddhist Council of New South Wales. Buddhist Organisations in New South Wales. http:// www.cse.unsw.edu.au/ s2145016/. n.d. Information obtained on 27th February, 1998.

Buddhist Council of New South Wales. Directory. http://www.zip.com.au/ lyallg/index6.htm. n.d. Information obtained on 26th November, 1998. 
Buddhist Federation of Australia. "Buddhist News: Census 1991." Buddhism Today: Journal of the Buddhist Federation of Australia 6 (2, April), 1991: 18.

Buddhist Federation of Australia. "Federation News." Buddhism Today: Journal of the Buddhist Federation of Australia 88(3), 1988: 4-7.

Buddhist Peace Fellowship. Buddhist Peace Fellowship. http://www.bpf.com/bpf/index.html. 26 February 1998. Information obtained on 26th November, 1998.

Buddhist Society of Western Australia. Nuns' Monastery. http://www.iinet.net.au/ ansonb/bswa/ nunmonas.html. 6 June 1998. Information obtained on 26th November, 1998.

Cox, David. Religion and Welfare: A Study of the Role of Religion in the Provision of Welfare Services to Selected Groups of Immigrants in Melbourne, Australia. Parkville, Victoria: Department of Social Studies, University of Melbourne, 1982.

Croucher, Paul. Buddhism in Australia 1848-1988. Kensington, New South Wales: New South Wales U. P., 1989.

Daw, Joan M. "Cultural and Religious Beliefs among Vietnamese Immigrants in Melbourne." Minor dissertation, Master of Arts, Melbourne Centre for Australian Studies, Monash University, Melbourne, 1994.

de Jong, Klaas. A Short Account of the Spread of Southern Buddhism in Australia and Queensland in Particular. Brisbane: Dhammadinna House, 1982.

Department of Immigration, Local Government and Ethnic Affairs. Directory of Ethnic Community Organisations in Australia. Canberra: Australian Government Publishing Services, 1992.

Dzogchen Community of Australia. http://www.buddhanet.net/ba26.htm. n.d. Information obtained on 26th November, 1998.

Fields, Rick. "Confessions of a White Buddhist." Tricycle: The Buddhist Review 4 (1), 1994: 54-56.

Fields, Rick. "The Future of American Buddhism." Vajradhatu Sun 9 (1), 1987: 1, 22, 24-26.

Fields, Rick. How the Swans Came to the Lake: A Narrative History of Buddhism in America. Boston: Shambhala, 1992, 3rd rev. ed.

Gamble, John. "The Buddhist Federation of Australia." Buddhism Today 1 (1, January), 1986: 4-9.

Hasslacher, Barbara. An Australian Directory of Spiritual Retreat Centres. PO Box 71, St Peters, 2044: The Author, 1995.

Hughes, Philip J. Religion in Australia: Facts and Figures. Kew Victoria: Christian Research Association, 1997.

Humphreys, Robert \& Ward, Rowland, eds. Religious Bodies in Australia: A Comprehensive Guide. Wantirna, Victoria: New Melbourne Press, 1995, 3rd ed.

Kantowsky, Detlef. "Buddhist Modernism in the West/Germany." In Everding, U., ed. Buddhism and Christianity: Interactions between East and West. Colombo: Goethe-Institut, 1995: 101-115.

Kearney, Patrick. Still Crazy after all these Years: Why Meditation isn't Psychotherapy. http:// www.buddhanet.net/crazy.htm. n.d. Information obtained on 26th November, 1998.

Khadro, Yeshe. "From Catholic Farm Girl to Buddhist Nun." In Metcalf, B., ed. From Utopian Dreaming to Communal Reality: Co-operative Lifestyles in Australia. Sydney: University of New South Wales Press, 1995: 115-126.

Khantipalo, Thera. "Foreword." In Croucher, P. Buddhism in Australia 1848-1988. Kensington, New South Wales: New South Wales U. P., 1989: vii-viii.

Knight, Chas [Charles] F. "Buddhism Gets a Hold in Australia." World Buddhism 1961: 23-24.

Kornfield, Jack. "Is Buddhism Changing in North America?" In Morreale, D., ed. Buddhist America. Santa Fe: John Muir Publications, 1988: xi-xxviii.

Lyall, Graeme. "Buddhism: Australia's Reaction to a New Phenomenon." Without Prejudice 7, 1994: 30-35.

Lyall, Graeme. "Ethnic Buddhists in New South Wales." In Ata, A. (I.) W., ed. Religion and Ethnic Identity: An Australian Study. Vol. 3. Richmond, Victoria: Spectrum Publications, 1989: 6-30.

Masefield, P. "Buddhism in Australia." UNIBUDS Annual Magazine 1981 /82: 18-21.

McDonnell, Terrance. "Buddhist Council." Vimamsa: Journal of the Buddhist Society of Queensland 5 (4), 1986: 17-18.

McDonnell, Terrance \& Bucknell, Rod. "Buddhists." In Gillman, I., ed. Many Faiths, One Nation. Sydney: Collins, 1988: 318-331.

McKimm, Inta B. "The First Mahayana Meditation Centre in Queensland." Metta: Journal of the Buddhist Federation of Australia 16 (5, March), 1975: 9-12.

Mohr, Michael. Zen Centres of Australia. http://www.iijnet.or.jp/iriz/irizhtml/centers/australi.htm. 20th December, 1997. Information obtained on 24th December, 1997. 
Numrich, Paul D. Old Wisdom in the New World: Americanisation in two Immigrant Theravada Buddhist Temples. Knoxville: University of Tennessee Press, 1996.

Pearce, M. "The Beginnings of Buddhism in Australia." Karuna February, 1981: 3-12.

Prebish, Charles. "Ethics and Integration in American Buddhism." Journal of Buddhist Ethics 2, 1995: 125-139. http://jbe.la.psu.edu/2/pre3abs.html. Information obtained on 26th November, 1998.

Prebish, Charles. "Two Buddhisms Reconsidered." Buddhist Studies Review 10 (2), 1996: 187-206

Rigney, Helen. "Buddhism: Bridging the Cultural Gap." Migration December-January 1989-1990: $12-13$.

Schiller, Lauren M. "Buddhism in Contemporary America." M.Sc. dissertation, Southern Connecticut University, 1994.

Spuler, Michelle. Buddhism in Australia: A Bibliography. http://www.uq.edu.au/ remspule/biblio.html. 1998. Information obtained on 24th December, 1998.

Spuler, Michelle. "Directory of Buddhist Societies in Brisbane." Unpublished Honours dissertation, Department of Studies in Religion, University of Queensland, 1994.

Tweed, Thomas A. “The American Encounter with Buddhism, 1844-1912: Responses to Buddhism, Dissent and Consent, and Victorian Religious Culture." Ph.D. dissertation, Stanford University, 1989.

Young, Nico. "The Buddhist Society of Queensland." Metta: Journal of the Buddhist Federation of Australia 25 (3), 1983: 3-4. 